\title{
Corporate Social Responsibility in Family and Non-Family SMEs in Mexico
}

\author{
Gonzalo Maldonado-Guzman ${ }^{1}$, Sandra Yesenia Pinzón-Castro ${ }^{1}, \&$ Araceli Alvarado-Carrillo ${ }^{2}$ \\ ${ }^{1}$ Centro de Ciencias Económicas y Administrativas, Universidad Autonoma de Aguascalientes, Mexico \\ ${ }^{2} \mathrm{PhD}$ Student, Centro de Ciencias Económicas y Administrativas, Universidad Autónoma de Aguascalientes, \\ México \\ Correspondence: Gonzalo Maldonado-Guzman, Centro de Ciencias Económicas y Administrativas, Universidad \\ Autonoma de Aguascalientes, Aguascalientes, Mexico, Avenida Universidad No. 940, Ciudad Universitaria, C.P. \\ 20131, México.
}

Received: June 29, 2018

doi:10.5539/ibr.v11n8p171
Accepted: July 14, 2018

Online Published: July 27, 2018

URL: https://doi.org/10.5539/ibr.v11n8p171

\begin{abstract}
Corporate social responsibility (CSR) has been practically oriented towards large companies, and few studies have analyzed this construct in a context of family businesses, but there are few studies that relate CSR in small and medium-sized enterprises Family businesses (SMEs) and non-family businesses. Therefore, this empirical study has the essential objective of analyzing CSR in a context of family and non-family SMEs in Mexico. The results show that CSR is exactly the same in both family SMEs and non-family SMEs in Mexico.
\end{abstract}

Keywords: corporate social responsibility, family firms, SMEs

\section{Introduction}

The debate related to Corporate Social Responsibility (CSR) in the current literature of business and management sciences has focused mostly on big enterprises (Baumann-Pauly et al., 2013), especially in multinational ones (Spence, 2007; Jamali et al., 2009; Ladzani \& Seeletse, 2012). However, there are relatively few theoretical and empirical investigations focused on the analysis and discussion of CSR in small and medium-sized enterprises (SMEs) (Bevan \& Yung, 2015; Jamali et al., 2017), especially about SMEs in developing countries (Khan \& Lund-Thomsen, 2011; Amaeshi et al., 2016; Jamali et al., 2017). There are even less researches published in the literature that analyzes CSR in family and non-family SMEs (Déniz \& Cabrera, 2005; Amman et al., 2012; Campopiano \& De Massis, 2014; Yu et al., 2015).

Even when researchers and scholars have acknowledged the importance of family enterprises in the economy and society for both developed and developing countries, as it is the case of Mexico, (Gersick et al., 1997; Neubauer \& Lank, 1998; Dyer, 2003; Chua et al., 2003), because according to the most recent estimates it is said that, on average, family enterprises represent around $60 \%$ of the existing enterprises in countries (Déniz \& Cabrera, 2005). Despite this, the analysis and discussion about the nature and operation of family enterprises and more specifically the discussion of the existing CSR in this type of enterprises mostly in family SMEs has received little attention from researchers and scholars (Gersick et al., 1997; Chua et al., 1999; Déniz \& Cabrera, 2005).

Similarly, it is possible to find investigations in the current literature that imply that family enterprises tend to make decisions that allows them to be more socially responsible than non-family ones (Dyer \& Whetten, 2006; Berrone et al., 2010). Moreover, Gómez-Mejía et al. (2007) concluded in their research that the control exerted by the owner of the family firm makes the rest of the family more conservative except when they take risks to improve the control of the firm. Thus, SMEs generally diminish the negative impacts of their industrial activities and make the most of their positive impacts through the improvement of social, economic and environmental problems as well as they contribute significantly to the development of the community and the society where they belong to which creates a higher level of social responsibility (Rundle-Thiele et al., 2008; Lindgreen \& Swaen, 2010).

Consequently, Quazi and O'Brien (2000) made an extensive review of the literature and summarized accurately the different approaches that enterprises have about CSR by creating a model that includes two basic dimensions: 
the span in which the CSR activities take place and the rank of the results of this social commitment. Nonetheless, this investigation is not conclusive and it is necessary to carry out more empirical researches that provide more evidence of the CSR that SMEs have so this can be integrated to the biggest sector of organizations, that is, small family enterprises (Dyer, 2003). Additionally, it is also needed more research papers that identify and analyze the different types of behaviors that family and non-family firms have (Déniz \& Cabrera, 2005), including CSR (Yu et al., 2015).

Within this context, and following the suggestions of Uhlaner and Masuerl (2004), Déniz and Cabrera (2005), Campopiano and De Massis (2014), as well as Yu et al. (2015), the main contribution of this empirical research is the analysis and discussion of CSR in family and non-family SMEs, from a country with an emerging economy as it is the case of Mexico. Another contribution of this investigation could be the methodology used since it will apply the model of multi-group structural equations to test the projected theoretical model. The rest of the paper has been organized in the following way: the second section makes a review of the theoretical framework, the previous empirical researches and the establishment of the research hypothesis; the third section presents the methodology, the sample and the variables used; the fourth section analyzes the results obtained and, in the final section, the main conclusions and the discussion of the empirical research are presented

\section{Method}

The discussion and analysis of CSR as one of the main business topics has taken place since the beginning of the last century (f.e. Berle, 1931; Dodd, 1932) and now in the present its conceptualization is still a debate (Yu et al., 2015) as there is not a clear consensus among researchers and scholars of a convincing definition although generally most authors consider that the definition must include the "triple bottom line" principles (people, planet and profit) (Yu et al., 2015). In this context, one of the closest definitions to these three principles is the one developed by Aguinis (2011: 855), who defines CSR as a "specific context of organizational actions and policies that take into account the expectations of suppliers and the social, economic and environmental actions".

Accordingly, in the literature of business and management sciences, there are several definitions of family firm, but there is not a current consensus about a definition accepted by most researchers and scholars (Amann et al., 2012). However, Villalonga and Amit (2004), as well as Allouche et al. (2008), suggested that any definition of family enterprise must include three essential elements: 1) one or more families will need to have most of the capital; 2) the family members will need to have most of the control of the enterprise including the distribution of capital, most of the rights to vote in the organization as well as the legal restrictions and, 3) the members of the family will have to be in the administrative positions of the enterprise.

Despite the increase of theoretical and empirical investigations in the last decade, there are relatively few researches that have focused in the analysis of CSR in family firms (Yu et al., 2012; Amman et al., 2012; Yu et al., 2015), and more recently the publication of this topic has increased in family firms (Déniz \& Cabrera, 2005; Craig \& Dibrell, 2006; Dyer, 2006; Niehm et al., 2008; Huang et al., 2009; Berrone et al., 2010; Bingham et al., 2011; Neubaum et al., 2012; Amann et al., 2012; Block \& Wagner, 2014; Van Gils et al., 2014; Yu et al., 2015). It is also common to find in the literature papers that analyze family and non-family enterprises through the return of investments (Anderson \& Reeb, 2003), the growth in sales (Daily \& Dollinger, 1992; Gallo et al., 2000; Chrisman et al., 2004), the level of satisfaction in the job (Beehr et al., 1997), the innovation (Tanewski et al., 2003) and, more recently, CSR (Deniz \& Cabrera, 2005; Dyer \& Whetten, 2006).

Moreover, some previous investigations published in the current literature suggest that small family firms can tend more to the implementation of CSR activities (f.e. Uhlaner et al., 2004; Déniz \& Cabrera, 2005; Block \& Wagner, 2010) since one of the main arguments is that family enterprises have a better understanding of the reputation of the enterprise than those who are non-family organizations (Amann et al., 2012). Consequently, Block and Wagner (2010) compared the different types of owners of small enterprises and concluded that the proprietors of small family firms have a higher reputation about their social responsibility in the communities where they are located.

Furthermore, it can also be found in the literature another explanation that complements the previous one which considers that the long term orientation of these small family enterprises is better when compared with non-family firms (Amann et al., 2012). This long-term orientation refers basically to the main shareholders of the family in the enterprise who have a vision of preserving the ownership of the small family firm through generational inheritance (Abdellatif et al., 2010). Likewise, Le Breton-Miller and Miller (2006) concluded that the long-term orientation allows family enterprises to attain organizational characteristics that are difficult to be imitated or copied by their competitors and at the same time these characteristics allow them to develop policies 
for long-term investments in order to improve their corporate image.

In a similar trend, Graafland (2002) considered that most small family enterprises have a positive between value addition in the long term and their corporate image; that is why they are more focused in the implementation of bigger CSR actions than non-family firms. Following a similar reasoning of the long term orientation Block and Wagner (2010) established that family firms that have adopted and implemented a long term orientation usually have a higher relation with their clients and suppliers when compared with non-family enterprises which can often be observed in the significant increase of social responsibility actions that small family organization carry out and, consequently, a higher level of CSR.

Within this idea of long term orientation, small family firms usually protect their employees better, they get more involved in social and philanthropic activities in their communities, they implement management policies of their integrity regarding their business reputation and they respect the family values and traditions of their employees and the community when compared with non-family firms (Donnelly, 1964; Ward, 1987; Leach, 1993; Poza, 1995; Neubauer \& Lank, 1998; Miller \& Le Breton-Miller, 2003). These special actions and characteristics that small family firms have is not only a source of competitive advantages but it is also the basis of resources, and specific abilities that become difficult for their main competitors to copy and imitate them (Ward, 1999; Habbershon \& Williams, 1999; Cabrera et al., 2001; Gnan \& Montemerlo, 2002), and producing with this a higher level of CSR (Déniz \& Cabrera, 2005).

Similarly, there are other published investigations in the literature that establish that small family firms have a socially responsible behavior that is higher than non-family ones (Amann et al., 2012). Thus, for example, Adams et al. (1996) analyzed the ethical behavior of family and non-family firms but their results did not show any significant difference between them. However, theses researchers considered some arguments to differentiate the ethical behavior of family and non-family enterprises by using, for example, the long-term orientation that family firms have (f.e. Dyer, 2003; Zellweger, 2007), which produces not only a higher ethical behavior in family companies over non-family organizations (Long \& Mathews, 2011), but also a higher social responsibility in their strategic decisions (Chrisman et al., 2012; Kotlar \& De Massis, 2013).

Moreover, the strategies adopted and implemented by family firms are usually associated to their ethical behavior (Donckels \& Frohlich, 1991), which allows family companies to be more progressive than non-family organizations in terms of their human resources and in their social responsibility (Aldricht \& Langton, 1998; Reid \& Adams, 2001; Colombo et al., 2014). Accordingly, Dyer and Whetten (2006) proved that there are no significant differences between family and non-family firms regarding the implementation of support to their employees, the society and the environment but they did find that family companies tend to be more cautious in the social actions that they develop, in the protection of their reputation and validate their social responsibility in the community where they are located when compared with non-family firms.

In this regard, small family firms have more social pressure in the implementation of business actions and activities that ensure a better conservation of the environment (social responsibility) of the area or community where they are located (Yu et al., 2015) since this type of pressure is generally associated with the high level of concentration in the specialization of only one product or service or in the geographic limitation where small family companies work (Berrone et al., 2010). Consequently, it is possible to find in the literature some investigations that have proved that family enterprises tend to adopt and develop innovations that are more well-intentioned with the environment than non-family companies which makes them more socially responsible and better connected with the area or community where they are located (Zellweger \& Nason, 2008; Huang et al., 2009).

According to this perspective, small family firms have a higher social commitment to protect and maintain the environment because such commitment does not only reinforce the affective bonds but also keep the socio-emotional richness from both the members of the family enterprise and the community in general (Gómez-Mejía et al., 2007; Berrone et al., 2010; Cennamo et al., 2012). As a result, this perception provides small family firms with access to the different resources of the family (Sirmon \& Hitt, 2003; Arregle et al., 2007) facilitating with this the creation and development of a family identity, a bigger emotional capital (Sharma, 2004) and strong family values (Dyer, 2003) creating with this a higher CSR and the implementation of better environmental corporate practices (Cennamo et al., 2012).

Within this perspective, Berrone et al. (2010) concluded that the socio-emotional richness of family firms is one of the most solid arguments that explain why families do not only have a better control of the enterprises but they are also more committed with the protection and preservation of the environment than non-family enterprises. Therefore, the socio-emotional richness creates a higher social commitment in small family firms 
(Gómez-Mejía et al., 2007; Berrone et al., 2010) and a significant increase in the level of economic resources of the family enterprise (Gómez-Mejía et al., 2007) and it is one of the essential elements that allow that the behavior of small family enterprises is completely stimulated by the achievement of economic and non-economic goals as it is the case of CSR (Kotlar et al., 2013). Thus, at this point, it is possible to establish the following research hypothesis:

\section{$H_{1}$ : Family and non-family SMEs are different in their CSR practices.}

\subsection{Sampling Procedures}

In order to answer the research hypothesis stated in this research paper, an empirical investigation was made with a sample of 400 small and medium-sized enterprises from Aguascalientes State (Mexico). For the research it was considered the 2016 business directory of the Sistema de Información Empresarial Mexicano (System of Mexican Business Information, or SIEM) for Aguascalientes State which had 5,194 registered enterprises in December 2016 but for practical purposes the only enterprises considered for this research were the ones that had from five to 250 workers which produced a business directory of 1,261 enterprises. Additionally, the sample was selected randomly with a reliability level of $96 \%$ and a sampling error of $\pm 4.5 \%$, which produced a total sample of 400 enterprises. The interviews were made from January to April 2016.

Similarly, the instrument used was a questionnaire, which was applied as a personal interview to managers and/or owners of the 400 selected enterprises. Moreover, from the total of questionnaires obtained, 264 (66\%) were considered as family firms and $136(34 \%)$ as non-family companies. Finally, the questionnaire obtained information regarding the characteristics of the enterprises (family and non-family SMEs) as well as the adoption and implementation of socially responsible business activities of SMEs.

\subsection{Measures and Covariates}

Accordingly, the scale adapted from the European Union (2001), Bloom and Gundlach (2001), Bigné et al. (2005) as well as Alvarado and Schlesinger (2008), was used for the measurement of business social responsibility. They considered that CSR can be measured easily through three dimensions: social responsibility (measured by means of a ten-item scale), environmental responsibility (measured by means of a seven-item scale), and economic responsibility (measured by means of a seven-item scale). All the items of the CSR scale are based on a Likert-type scale of five positions from " $1=$ completely disagree to $5=$ completely agree" as limits.

Furthermore, the reliability and validity of the CSR scale was evaluated with a Multiple-group Confirmatory Factorial Analysis (MCFA), by using the method of maximum likelihood with the software EQS 6.1 (Bentler, 2005; Brown, 2006; Byrne, 2006). Furthermore, the reliability of the five scales considered in this empirical research was evaluated with two essential indices: Cronbach's alpha and the Composite Reliability Index (CRI) (Bagozzi \& Yi, 1988). Additionally, the recommendations made by Chou et al. (1991) and by Hu et al. (1992), were taken into consideration regarding the correction of statistics of the theoretical model when it is considered that the normalcy of data is present as well as the robust statistics in order to provide a better statistical adjustment of the data (Satorra \& Bentler, 1988).

Additionally, the adjustments indices used were the Index of Normalized Adjustment (NFIT), the Index of Not Normalized Adjustment (NNFIT), the Index of Comparative Adjustment (CFI) and the Root Mean Square of Error Approximation (RMSEA) (Bentler \& Bonnet, 1980; Byrne, 1989; Bentler, 1990; Hair et al., 1995; Chau, 1997; Heck, 1998). If the NFIT, NNFIT and CFI values are between 0.80 and 0.89 then it can be said that there is a reasonable adjustment of the theoretical model (Segars \& Grover, 1993). Conversely, if the average of these three indices is equal or higher than 0.90 then it is an evidence of an excellent adjustment of the theoretical model (Jöreskog \& Sörbom, 1986; Byrne, 1989; Papke-Shields et al., 2002). If the RMSEA value is lower than 0.080, it is considered as acceptable (Jöreskog \& Sörbom, 1986, Hair et al., 1995). 
Table 1. Internal consistency and convergent validity of the theoretical model

\begin{tabular}{|c|c|c|c|c|c|c|}
\hline Variable & Indicator & $\begin{array}{c}\text { Factorial } \\
\text { Loading }\end{array}$ & $\begin{array}{l}\text { Robust } \\
\text { t-Value }\end{array}$ & $\begin{array}{c}\text { Cronbach's } \\
\text { Alpha }\end{array}$ & CRI & IVE \\
\hline \multicolumn{7}{|c|}{ Family SMEs } \\
\hline \multirow{7}{*}{ Social Responsibility } & RSS2 & $0.642 * * *$ & $1.000^{\mathrm{a}}$ & \multirow{7}{*}{0.913} & \multirow{7}{*}{0.914} & \multirow{7}{*}{0.606} \\
\hline & RSS5 & $0.688 * * *$ & 9.235 & & & \\
\hline & RSS6 & $0.740 * * *$ & 10.546 & & & \\
\hline & RSS7 & $0.810 * * *$ & 11.120 & & & \\
\hline & RSS8 & $0.867 * * *$ & 11.555 & & & \\
\hline & RSS9 & $0.883 * * *$ & 11.640 & & & \\
\hline & RSS10 & $0.788 * * *$ & 11.003 & & & \\
\hline \multirow{6}{*}{ Environmental Responsibility } & RSA1 & $0.918 * * *$ & $1.000^{\mathrm{a}}$ & \multirow{6}{*}{0.915} & \multirow{6}{*}{0.916} & \multirow{6}{*}{0.636} \\
\hline & RSA3 & $0.718 * * *$ & 14.577 & & & \\
\hline & RSA4 & $0.750 * * *$ & 15.337 & & & \\
\hline & RSA5 & $0.792 * * *$ & 16.192 & & & \\
\hline & RSA6 & $0.847 * * *$ & 17.398 & & & \\
\hline & RSA7 & $0.785 * * *$ & 15.762 & & & \\
\hline \multirow{5}{*}{ Economic Responsibility } & RSE2 & $0.648 * * *$ & $1.000^{\mathrm{a}}$ & \multirow{5}{*}{0.859} & \multirow{5}{*}{0.860} & \multirow{5}{*}{0.555} \\
\hline & RSE4 & $0.654 * * *$ & 9.300 & & & \\
\hline & RSE5 & $0.810 * * *$ & 10.464 & & & \\
\hline & RSE6 & $0.809 * * *$ & 10.339 & & & \\
\hline & RSE7 & $0.788 * * *$ & 9.682 & & & \\
\hline \multicolumn{7}{|c|}{ Non-Family SMEs } \\
\hline \multirow{7}{*}{ Social Responsibility } & RSS2 & $0.642^{* * * *}$ & $1.000^{\mathrm{a}}$ & \multirow{7}{*}{0.902} & \multirow{7}{*}{0.903} & \multirow{7}{*}{0.575} \\
\hline & RSS5 & $0.681 * * *$ & 9.235 & & & \\
\hline & RSS6 & $0.691 * * *$ & 10.546 & & & \\
\hline & RSS7 & $0.777 * * *$ & 11.120 & & & \\
\hline & RSS8 & $0.857 * * *$ & 11.555 & & & \\
\hline & RSS9 & $0.866^{* * *}$ & 11.640 & & & \\
\hline & RSS10 & $0.763 * * *$ & 11.003 & & & \\
\hline \multirow{6}{*}{ Environmental Responsibility } & RSA1 & $0.809^{* * *}$ & $1.000^{\mathrm{a}}$ & \multirow{6}{*}{0.908} & \multirow{6}{*}{0.909} & \multirow{6}{*}{0.625} \\
\hline & RSA3 & $0.735^{* * *}$ & 14.577 & & & \\
\hline & RSA4 & $0.777 * * *$ & 15.537 & & & \\
\hline & RSA5 & $0.803 * * *$ & 16.192 & & & \\
\hline & RSA6 & $0.854 * * *$ & 17.398 & & & \\
\hline & RSA7 & $0.761 * * *$ & 15.762 & & & \\
\hline \multirow{5}{*}{ Economic Responsibility } & RSE2 & $0.615^{* * *}$ & $1.000^{\mathrm{a}}$ & \multirow{5}{*}{0.862} & \multirow{5}{*}{0.863} & \multirow{5}{*}{0.56} \\
\hline & RSE4 & $0.628 * * *$ & 9.300 & & & \\
\hline & RSE5 & $0.831 * * *$ & 10.464 & & & \\
\hline & RSE6 & $0.854 * * *$ & 10.739 & & & \\
\hline & RSE7 & $0.786 * * *$ & 15.762 & & & \\
\hline$S-B X^{2}(\mathrm{df}=276)=426.5$ & $\mathrm{p}<0.000$ & $\mathrm{FFI}=0.882$ & $\mathrm{FI}=0.89$ & $\mathrm{FI}=0.929 ; \mathrm{R}$ & $\mathrm{SEA}=0$ & \\
\hline
\end{tabular}

The results of the MCFA are presented in Table 1 and they suggest that the theoretical model of business social responsibility has a good adjustment $\left(S-B X^{2}=426.525 ; d f=276 ; p=0.000 ; N F I=0.882 ; N N F I=0.899 ; C F I=\right.$ 0.929; RMSEA = 0.052). All the items of the related factors are significant $(\mathrm{p}<0.001)$, the size of all the standardized factorial loads are higher than 0.60 as recommended by Bagozzi and Yi, 1988; Cronbach's alpha and the CRI have a value higher than 0.70 and the variance extracted index (VEI) has a value higher than 0.50 (Fornell \& Larcker, 1981). These values indicate that there is enough evidence of reliability and convergent validity, which justifies the internal reliability of the CSR scale used (Nunally \& Bernstein, 1994; Hair et al., 1995).

Likewise, a reliability interval test was carried out in order to evaluate the discriminant validity of the CSR model, for both family and non-family firms proposed by Anderson and Gerbing (1988). It establishes that with an interval of $95 \%$ of reliability none of the individual latent elements of the matrix of correlation must have a value of 1.0 for both family and non-family SMEs. Therefore, based on the results obtained (with the same results for family and non-family firms) from this test, it can be concluded that that both measurements provide enough evidence of discriminant validity of the theoretical model. These results can be observed in detail in Table 2. 
Table 2. Discriminant validity of the theoretical model

\begin{tabular}{ccccccc}
\hline \multicolumn{1}{c}{ Variables } & Social Responsibility & \multicolumn{2}{c}{$\begin{array}{c}\text { Environmental } \\
\text { Responsibility }\end{array}$} & \multicolumn{2}{c}{ Economic Responsibility } \\
\hline Social Responsibility & & $0.256-0.427$ & $0.293-0.385$ \\
\hline Environmental Responsibility & $0.256-0.427$ & & & $0.268-0.404$ \\
\hline Economic Responsibility & $0.293-0.385$ & $0.268-0.404$ & & \\
\hline
\end{tabular}

Above the diagonal the estimated correlation of factors is presented with $95 \%$ confidence interval of the Family SMEs. Below diagonal, the estimated correlation of factors is presented with $95 \%$ confidence interval of the Non-Family SMEs.

\section{Results}

In order to prove the hypothesis presented in this empirical research, a structural equations model (SEM) with software EQS 6.1 was applied (Bentler, 2005; Byrne, 2006; Brown, 2006). In it, the nomological validity of the theoretical model of CSR was examined through the Chi-square test, which compared the results obtained between the theoretical model of CSR and the measurement model of CSR. Such results indicate that the differences between both models are not significant which can offer an explanation of the relationships observed among the latent constructs (Anderson \& Gerbing, 1988; Hatcher, 1994). Figures 1 and 2 show a path analysis of these results for both family and non-family SMEs.

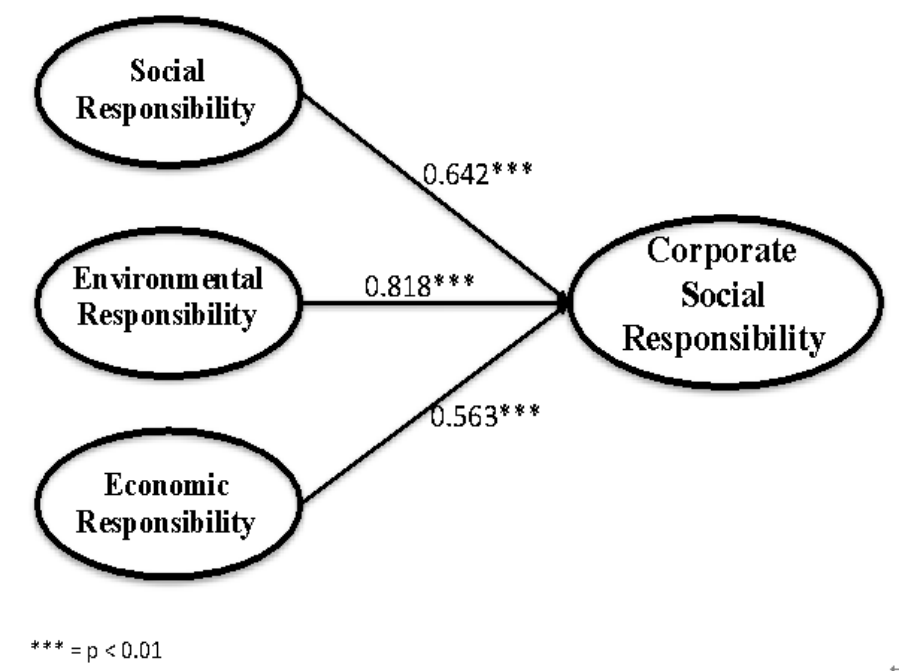

Figure 1. Results of the structural equation model of Family SMEs

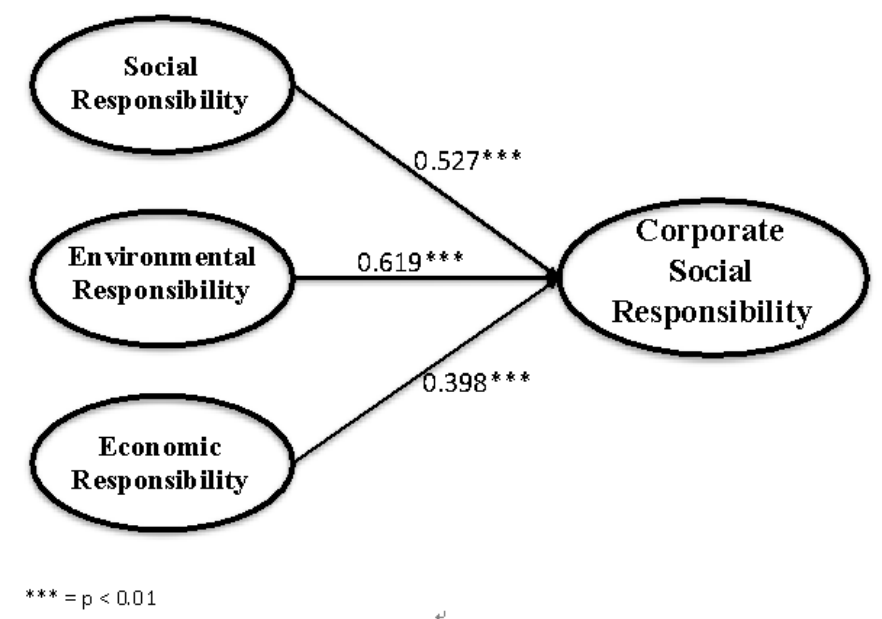

Figure 2. Results of the structural equation model of Non-Family SMEs

As it can be seen in Figures 1 and 2, small family firms have better results in the implementation of CSR activities $(0.642 ; 0.818 ; 0.563)$, than small non-family firms $(0.527 ; 0.619 ; 0.398)$, which can validate the hypothesis established about the existence of differences in CSR activities between family and non-family 
enterprises. Accordingly, both family and non-family firms develop more activities of environmental responsibility followed by social and economic responsibility but then again family organizations have better results. Thus, it is possible to conclude that the results obtained show that small family firms have better results of the adoption and implementation of CSR activities than small non-family firms and that the environmental responsibility is the most developed activity in both types of enterprise.

\section{Discussion}

The results obtained in this empirical research can conclude three main aspects. Firstly, the adoption and implementation of social activities carried out by family SMEs in communities or regions where they are located produce a higher level of social responsibility when compared with non-family SMEs. For this reason, the philanthropic activities carried out for family and non-family firms have a positive impact in the organization's image as a whole although non-family SMEs have a lower level of impact in their CSR. This can make that consumers and clients of products and services prefer the acquisition of the products or services from family SMEs instead of the ones from their main competitors.

Secondly, it is also possible to conclude that SMEs which carry out social activities regarding the protection of the environment have a bigger CSR impact than the activities implemented by non-family SMEs but the society of the communities or areas where they are located both family and non-family firms perceive that this type of enterprises promote significantly the protection of the environment of their community or are. Consequently, the development of the activities carried out by both family and non-family SMEs that promote the protection of the environment usually produce an acknowledgement not only as socially responsible SMEs but also as enterprises with a higher degree of acceptation of their products or services from consumers and clients both current and potential.

Finally, it is also possible to state that the economic activities implemented for both family and non-family SMEs have a smaller impact in CSR even when the results show that family SMEs carry out better economic support activities for their workers and the area or community where they are located this type of enterprise. Thus, the actions of economic support and improvement of the quality of life for the workers of both family and non-family SMEs and the society as a whole are appreciated by the people of the community or area although with a different emphasis from the social and environmental actions but this also gives them a higher level of social responsibility to family SMEs and a lower level to non-family SMEs

Similarly, the results obtained and the conclusions achieved also have different implications for both executives as well as family and non-family SMEs. Thus, a first implication could be that family firms usually have social values which are very similar to the ones of the society in the communities or areas where they are located since most workers and employees come from these places and even the very same family that owns the enterprise live in the same community or area which makes them known and respected families by the society as a whole. This creates a higher acknowledgement as enterprises that are socially responsible. Nonetheless, this does not happen with non-family SMEs which settle in industrial parks and they do not have values, similar organizations to the society in the communities or areas where they are located, not even the executives have ties with the society.

A second implication may be that the owners of family SMEs usually support economically to the development of social activities that highlight and promote religious and/or civic traditions of the communities or areas where they are located. This allows them not only to be recognized as an essential part for the growth and economic and social development of the area or community but also as socially responsible enterprises. The opposite thing happens to non-family SMEs, since generally the social traditions of the area or community where they are located are not part of their organizational culture and they do not sponsor their development. This avoids them from getting a similar rank of family SMEs, that is, they are not considered as socially responsible.

A third implication could be that family SMEs also usually have a good social reputation, not only for the production of products or services required by society, since generally this type of enterprises have a local or regional market, but they also contribute regularly with economic resources for the support and preservation of the environment of the community or area where they are located which allows them to be considered as socially responsible enterprises. On the other hand, non-family SMEs normally do not get involved in activities for the care and preservation of the environment of the area or community where they are located, they do not even provide economic elements for the preservation of natural resources which could be one of the main reasons to not consider them as socially responsible at the same level of family SMEs.

Finally, a fourth implication could be that family SMEs usually carry out philanthropic activities to benefit the society of the communities or areas where they are located since the values of the society are an essential part of the values and the culture of the very family organization. When they settle down, normally next to hospitals, 
schools and churches, these institutions ask for in-kind contributions or economic support for the development of their activities, which creates a big acknowledgement as enterprises that are socially responsible. However, non-family SMEs do not normally do this type of philanthropic contributions or get involved in the social activities of the community or area where they are located. This could be one of the main reasons that the members of a society do not consider them as socially responsible enterprises and they do not have a similar image to those that are family SMEs.

Additionally, this empirical research also has different limitations that are necessary to present. The first one is related to the use of the scale for the measurement corporate social responsibility of family and non-family SMEs since only three factors or dimensions were considered: social, economic and environmental responsibility. Future investigations will need to consider other factors or dimension in order to prove the results obtained. A second limitation could be the collection of information since the only variables considered for the measurement of corporate social responsibility of family and non-family SMEs were qualitative variables. Further researches will have to consider the incorporation of quantitative or hard data variables in order to check if the results obtained are the same as the ones of this research paper.

A third limitation could be the instrument to collect information that was applied only to managers and/or owners of family and non-family SMEs. Consequently, the results obtained in this research paper can change considerably if a different population is considered. Further investigations will need the implementation of an instrument to collect information of clients and consumers, for example, of family and non-family SMEs to verify the results obtained. A fourth limitation could also be that for practical purposes of this empirical research the only enterprises considered were the ones that had between five and 250 workers so in future studies it will be important to consider enterprises that have less than five workers as they represent a little over 50\% of enterprises in Mexico in order to verify the results obtained in this research paper.

Finally, a fifth limitation could be that a high percentage of family and non-family SMEs that were interviewed considered that the information requested was classified as confidential so the data provided by family and non-family firms may not necessarily reflect the reality of corporate socially responsible activities that are carried out by this type of enterprises. Further investigations will have to consider the direct participation of business committees or associations to avoid as much as possible the falsehood of the information requested from both family and non-family enterprises.

\section{References}

Abdellatif, M., Amann, B., \& Jaussaud, J. (2010). Family versus non-family business: A comparison of international strategies. Journal of Family Business Strategy, 1(2), 108-116. https://doi.org/10.1016/j.jfbs.2010.04.004

Adams, J., Taschian, A., \& Shore, T. (1996). Ethics in family and non-family owned firms: An exploratory study. Family Business Review, 9(2), 157-170. https://doi.org/10.1111/j.1741-6248.1996.00157.x

Aguinis, H. (2011). Organizational responsibility: Doing good and doing well. In S. Zedeck (Ed.), APA Handbook of Industrial and Organizational. Washington, DC: American Psychological Association. https://doi.org/10.1037/12171-024

Aldrich, H. E., \& Langton, N. (1998). Human resource management and organizational life cycles. In P. Reynolds, et al. (Eds.), Frontiers of Entrepreneurship Research. Babson Park, MA: Babson College, Center for Entrepreneurial Studies.

Allouche, J., Amann, B., Jaussaud, J., \& Kurashina, T. (2008). The impact of family control on the performance and financial characteristics of family versus non-family businesses in Japan: A matched-pair investigation. Family Business Review, 21(4), 315-329. https://doi.org/10.1177/08944865080210040104

Alvarado, H., \& Schlesinger, M. (2008). Dimensionalidad de la responsabilidad social empresarial percibida y sus efectos sobre la imagen y la reputación: Una aproximación desde el modelo de Carroll. Estudios Gerenciales, 24(108), 37-59. https://doi.org/10.1016/S0123-5923(08)70043-3

Amaeshi, K., Adegbite, E., Ogbechie, C., Idemudia, U., Seny, K. A., Issa, M., \& Anakwue, O. I. J. (2016). Corporate social responsibility in SMEs: A shift from philanthropy to institutional works. Journal of Business Ethics, 138(1), 384-400. https://doi.org/10.1007/s10551-015-2633-1

Amann, B., Jaussaud, J., \& Martínez, I. (2012). Corporate social responsibility in Japan: Family and non-family business differences and determinants. Asian Business Management, 11(3), 329-345. https://doi.org/10.1057/abm.2012.6 
Anderson, J., \& Gerbing, D. (1988). Structural equation modeling in practice: a review and recommended two-step approach. Psychological Bulletin, 13, 411-423. https://doi.org/10.1037/0033-2909.103.3.411

Anderson, R. C., \& Reeb, D. M. (2003). Founding-family ownership and firm performance: Evidence from the S\&P 500. Journal of Finance, 58(3), 1301-1328. https://doi.org/10.1111/1540-6261.00567

Arregle, J. L., Hitt, M. A., Sirmon, D. G., \& Very, P. (2007). The development of organizational social capital: Attributes of family firms. Journal of Management Studies, 44(1), 73-95. https://doi.org/10.1111/j.1467-6486.2007.00665.x

Bagozzi, R. P., \& Yi, Y. (1988). On the evaluation of structural equation models. Journal of the Academy of Marketing Science, 16(1), 74-94. https://doi.org/10.1007/BF02723327

Baumann-Pauly, D., Wickert, C., Spence, L. J., \& Scherer, G. (2013). Organizing corporate social responsibility in small and large firms: Size matters. Journal of Business Ethics, 115(1), 693-705. https://doi.org/10.1007/s10551-013-1827-7

Beehr, T., Drexler, J. A., \& Faulkner, S. (1997). Working in small firms' business: Empirical comparisons to non-family business. Journal of Organizational Behavior, 18(3), 297-312. https://doi.org/10.1002/(SICI)1099-1379(199705)18:3<297::AID-JOB805>3.0.CO;2-D

Bentler, P. M. (1990). Comparative fit indexes in structural models. Psychological Bulletin, 107(2), 238-246.

Bentler, P. M. (2005). EQS 6 structural equations program manual. Encino, CA: Multivariate Software.

Bentler, P. M., \& Bonnet, D. (1980). Significance tests and goodness of fit in analysis of covariance structures. Psychological Bulletin, 88(3), 588-606. https://doi.org/10.1037/0033-2909.88.3.588

Berle, A. A. (1931). Corporate powers as powers in trust. Harvard Law Review, 44(7), 1049-1074. https://doi.org/10.2307/1331341

Berrone, P., Cruz, C., Gómez-Mejía, L. R., \& Larraza-Kintata, M. (2010). Social-emotional wealth and corporate response to institutional pressures: Do family-controlled firms pollute less? Administrative Science Quarterly, 55(1), 82-113. https://doi.org/10.2189/asqu.2010.55.1.82

Bevan, E. A. M., \& Yung, P. (2015). Implementation of corporate social responsibility in Australian construction SMEs. Engineering Construction and Architectural Management, 22(3), 295-311. https://doi.org/10.1108/ECAM-05-2014-0071

Bigné, E., Andreu, L., \& Sanchez, G, I. (2005). Investigación en marketing turístico: Un análisis de las publicaciones en el período 1995-2003. XV Jornadas Hispano-Lusas de Gestión Científica, Sevilla.

Bingham, J. B., Dyer, W. G., Smith, I., \& Adams, G. L. (2011). A stakeholder identity orientation approach to corporate social performance in family firms. Journal of Business Ethics, 99(4), 565-585. https://doi.org/10.1007/s10551-010-0669-9

Block, J. H., \& Wagner, M. (2014). The effect of family ownership on different dimensions of corporate social responsibility: Evidence from large US firms. Business Strategy and the Environment, 23(7), 475-492. https://doi.org/10.1002/bse.1798

Bloom, P., \& Gundlach, G. (2001). Handbook of marketing and society. Thousand Oaks, CA: Sage Publications. https://doi.org/10.4135/9781452204765

Brown, T. (2006). Confirmatory factor analysis for applied research. New York, NY: The Guilford Press.

Byrne, B. (2006). Structural equation modeling with EQS, basic concepts, applications, and programming. 2th Edition, London: LEA Publishers.

Byrne, B. M. (1989), A Primer of LISREL: Basic applications and programming for confirmatory factor analysis analytic models. New York, NY: Springer. https://doi.org/10.1007/978-1-4613-8885-2

Cabrera, M. K., De Saá, P., \& García, D. J. (2001). The succession process from a resource and knowledge based view of the family firms. Family Business Review, 14, 37-47. https://doi.org/10.1111/j.1741-6248.2001.00037.x

Campopiano, G., \& De Massis, A. (2015). Corporate social responsibility reporting: A content analysis in family and non-family firms. Journal of Business Ethics, 129(1), 511-534.

https://doi.org/10.1007/s10551-014-2174-z

Cennamo, C., Berrone, P., Cruz, C., \& Gómez-Mejía, L. R. (2012). Socio-emotional wealth and proactive 
stakeholders' engagement: Why family-controlled firms care more about their stakeholders. Entrepreneurship Theory and Practice, 36(6), 1153-1173.

https://doi.org/10.1111/j.1540-6520.2012.00543.x

Chau, P. (1997). Reexamining a model for evaluating information center success using a structural equation modeling approach. Decision Sciences, 28(2), 309-334.

https://doi.org/10.1111/j.1540-5915.1997.tb01313.x

Chou, C. P., Bentler, P. M., \& Satorra, A. (1991). Scaled test statistics and robust standard errors for nonnormal data in covariance structure analysis. British Journal of Mathematical and Statistical Psychology, 44, 347-357. https://doi.org/10.1111/j.2044-8317.1991.tb00966.x

Chrisman, J. J., Chua, J. H., \& Litz, R. A. (2004). Comparing the agency cost of family and non-family firms. Entrepreneurship Theory and Practice, 28(4), 335-354. https://doi.org/10.1111/j.1540-6520.2004.00049.x

Chrisman, J., Chua, J. H., Pearson, A. W., \& Barnett, T. (2012). Family involvement, family influence, and family-centered non-economic goals in small firms. Entrepreneurship Theory and Practice, 36(2), 267-293. https://doi.org/10.1111/j.1540-6520.2010.00407.x

Chua, J. H., Chrisman, J. J., Sharma, P. (1999). Defining the family business by behaviour. Entrepreneurship Theory and Practice, 23(4), 19-39. https://doi.org/10.1177/104225879902300402

Chua, J. H., Chrisman, J. J., Steier, L. P. (2003). Extending the theoretical horizons of family business research. Entrepreneurship Theory and Practice, 27(4), 331-338. https://doi.org/10.1111/1540-8520.00012

Colombo, M. G., De Massis, A., Piva, E., Rossi-Lamastra, C., \& Wright, M. (2014). Sales and employment changes in entrepreneurial ventures with family ownership: Empirical evidence from high-tech industries. Journal of Small Business Management, 52(2), 226-245. https://doi.org/10.1111/jsbm.12100

Craig, J., \& Dibrell, C. (2006). The natural environment, innovation, and firm performance: A comparative study. Family Business Review, 19(4), 275-288. https://doi.org/10.1111/j.1741-6248.2006.00075.x

Daily, C. M., \& Dollinger, M. J. (1992). An empirical examination of ownership structure in family and professionally management firms. Family Business Review, 5(2), 113-127. https://doi.org/10.1111/j.1741-6248.1992.00117.x

Déniz, M. C., \& Cabrera M. K. (2005). Corporate social responsibility and family business in Spain. Journal of Business Ethics, 56(1), 27-41. https://doi.org/10.1007/s10551-004-3237-3

Dodd, E. M. (1932). For whom are corporate managers' trustees? Harvard Law Review, 45(7), 1145-1163. https://doi.org/10.2307/1331697

Donckels, R., \& Frohlich, E. (1991). Are family businesses really different? European experiences from STRATOS. Family Business Review, 4(2), 149-160. https://doi.org/10.1111/j.1741-6248.1991.00149.x

Donelly, R. G. (1964). The family business. Harvard Business Review, 1, 427-445.

Dyer, W. G. (2003). The family: The missing variable in organizational research. Entrepreneurship Theory and Practice, 27(4), 401-416. https://doi.org/10.1111/1540-8520.00018

Dyer, W. G. (2006). Examining the family effect firm on firm performance. Family Business Review, 19(4), 253-273. https://doi.org/10.1111/j.1741-6248.2006.00074.x

Dyer, W. G., \& Whetten, D. A. (2006). Family firms and social responsibility: Preliminary evidence from the S\&P 500. Entrepreneurship Theory and Practice, 30(6), 785-802. https://doi.org/10.1111/j.1540-6520.2006.00151.x

Fornell, C., \& Larcker, D. (1981). Evaluating structural equation models with unobservable variables and measurement error. Journal of Marketing Research, 18(1), 39-50. https://doi.org/10.2307/3151312

Gallo, G. A., Tapies, J., \& Cappuyns, K. (2000). Comparison of family and non-family business: Financial logic and personal preferences. Chair of Family Business IESE. Research Paper No. 406 BIS, University of Navarra, Barcelona.

Gersick, K. E., Davis, J. A., McCollom, M., \& Lansberg, I. (1997). Generation to generation: Life cycles of the family business. Harvard, MA: Harvard Business School Press.

Gnan, L., \& Montemerlo, D. (2002). The multiple facets of family firms' social role: Empirical evidence from Italian SMEs. Research Forum Proceedings of the Family Business Network $13^{\text {th }}$ Annual Conference. Helsinki, Finland. 
Gómez-Mejía, L. R., Haynes, K. T., Nuñez-Nickel, M., Jacobson, K. J. L., \& Moyano-Fuentes, J. (2007). Socio-emotional wealth and business risks in family-controlled firms: Evidence from Spanish olive oil mills. Administrative Science Quarterly, 52(1), 106-137. https://doi.org/10.2189/asqu.52.1.106

Graafland, J. J. (2002). Corporate social responsibility in family business. Paper presented at the Research Forum Proceedings of the Family Business Network $13^{\text {th }}$ Annual Conference. Helsinki, Finland.

Habbershon, T., \& Williams, M. (1999). A resource-based framework for assessing the strategic advantages of family firms. Family Business Review, 12(1), 1-25. https://doi.org/10.1111/j.1741-6248.1999.00001.x

Hair, J. F., Anderson, R. E., Tatham, R. L., \& Black, W. C. (1995). Multivariate data analysis with readings. New York, NY: Prentice-Hall.

Hatcher, L. (1994). A step by step approach to using the SAS system for factor analysis and structural equation modeling. Cary, NC: SAS Institute Inc.

Heck, R. H. (1998). Factor analysis: Exploratory and confirmatory approaches. In G.A. Marcoulides, (Ed.), Modern methods for business research. Mahwah, NJ: Lawrence Erlbaum Associates.

Hu, L. T., Bentler, P. M., \& Kano, Y. (1992). Can test statistics in covariance structure analysis be trusted? Psychological Bulletin, 112(2), 351-362. https://doi.org/10.1037/0033-2909.112.2.351

Huang, Y. C., Ding, H. B., \& Kao, M. R. (2009). Salient stakeholder voices: Family business and green innovation adoption. Journal of Management \& Organization, 15(3), 309-326. https://doi.org/10.1017/S1833367200002649

Jamali, D., Lund-Thomsen, P., \& Jeppensen, S. (2017). SMEs and CRS in developing countries. Business \& Society, 56(1), 11-22. https://doi.org/10.1177/0007650315571258

Jamali, D., Zanhour, M., \& Keshishian, T. (2009). Peculiar strengths and relational attributes of SMEs in the context of CSR. Journal of Business Ethics, 87(3), 355-377. https://doi.org/10.1007/s10551-008-9925-7

Jöreskog, K. G., \& Sörbom, D. (1986). LISREL VI: Analysis of linear structural relationships by maximum likelihood, instrumental variables and square methods. Moorsville, IN: Scientific Software.

Khan, F. R., \& Lund-Thomsen, P. (2011). CRS as imperialism: Towards a phenomenological approach to CRS in the developing world. Journal of Change Management, 11(1), 73-90. https://doi.org/10.1080/14697017.2011.548943

Kotlar, J., \& De Massis, A. (2013). Goal setting in family firms: Goal diversity, social interactions, and collective commitment to family-centered goals. Entrepreneurship Theory and Practice, 37(6), 1263-1288. https://doi.org/10.1111/etap.12065

Ladzani, M. W., Seeletse, S. M. (2012). Business social responsibility: How are SMEs doing in Gauteng, South Africa? Social Responsibility Journal, 8(1), 87-99. https://doi.org/10.1108/17471111211196593

Le Breton-Miller, I., \& Miller, D. (2006). Why do some family businesses out-compete? Governance, long-term orientations, and sustainable capability. Entrepreneurial Theory and Practice, 30(6), 731-746. https://doi.org/10.1111/j.1540-6520.2006.00147.x

Leach, P. (1993). La empresa familiar. Barcelona, SP: Ediciones Garnica

Lindgreen, A., \& Swaen, V. (2010). Corporate social responsibility. International Journal of Management Review, 12(1), 1-7. https://doi.org/10.1111/j.1468-2370.2009.00277.x

Long, R. G., \& Mathews, K. M. (2011). Ethics in the family firms: Cohesion through reciprocity and exchange. Business Ethics Quarterly, 21(2), 287-308. https://doi.org/10.5840/beq201121217

Miller, D., \& Le Breton-Miller, I. (2003). Challenge versus advantage in family business. Strategic Organization, 1, 127-134. https://doi.org/10.1177/1476127003001001222

Neubauer, F., \& Lank, A. G. (1998). The family business: Its governance for sustainability. London: McMillan Press LTD. https://doi.org/10.1007/978-1-349-14465-5

Neubaum, D. O., Dibrell, C., \& Craig, J. B. (2012). Balancing natural environmental concerns of internal and external stakeholders in family and non-family businesses. Journal of Family Business Strategy, 3(1), 28-37. https://doi.org/10.1016/j.jfbs.2012.01.003

Niehm, L. S., Swinney, J., \& Miller, N. J. (2008). Community social responsibility and its consequences for family business performance. Journal of Small Business Management, 46(3), 331-350. 
https://doi.org/10.1111/j.1540-627X.2008.00247.x

Nunnally, J. C., \& Bernstein, I. H. (1994). Psychometric theory. $3^{\text {a }}$ Ed. New York, McGraw-Hill.

Papke-Shields, K. E., Malhotra, M. J., \& Grover, V. (2002). Strategic manufacturing planning systems and their linkage to planning system success. Decision Science, 13(1), 1-30. https://doi.org/10.1111/j.1540-5915.2002.tb01634.x

Poza, M. E. (1995). A la sombra del roble: La empresa privada familiar y su continuidad. Ohio: Editorial Universitaria para la Empresa Familiar.

Quazi, A. M., \& O'Brien, D. (2000). An empirical test of a cross-national model of corporate social responsibility. Journal of Business Ethics, 25(1), 33-51. https://doi.org/10.1023/A:1006305111122

Reid, R., \& Adams, J. (2001). Human resource management: A survey of practices within family and non-family firms. Journal of European Industrial Training, 25(6), 310-320. https://doi.org/10.1108/03090590110401782

Rundle-Thiele, S., Ball, K., \& Gillespie, M. (2008). Raising the bar: From corporate social responsibility to corporate social performance. The Journal of Consumer Marketing, 25(4), 245-253. https://doi.org/10.1108/07363760810882434

Satorra, A., \& Bentler, P. M. (1988). Scaling corrections for chi square statistics in covariance structure analysis. American Statistics Association 1988 Proceedings of the Business and Economic Sections, 208-313.

Segars, A. H., \& Grover, V. (1993). Re-examining perceived ease of use and usefulness: A confirmatory factor analysis. MIS Quarterly, 17(4), 517-525. https://doi.org/10.2307/249590

Sharma, P. (2004). An overview of the field of family business studies: Current status and directions for the future. Family Business Review, 17(1), 1-36. https://doi.org/10.1111/j.1741-6248.2004.00001.x

Sirmon, D. G., \& Hitt, M. A. (2003). Managing resources: Linking unique resources, management, and wealth creation in family firms. Entrepreneurship Theory and Practice, 27(4), 339-358. https://doi.org/10.1111/1540-8520.t01-1-00013

Spence, L. (2007). CRS and small business in a European policy context: The five C's of CRS and small business research agenda 2007. Business and Society Review, 112(4), 533-552. https://doi.org/10.1111/j.1467-8594.2007.00308.x

Tanewski, G. A., Prajogo, D., \& Sohal, A. (2003). Strategic orientation and innovation performance between family and non-family firms. World Conference of the International Council of Small Business, Monash University, Caulfield East, Australia.

Uhlaner, L. M., Goor-Balk, H. J. M., \& Masurel, E. (2004). Family business and corporate social responsibility in a sample of Dutch firms. Journal of Small Business and Enterprise Development, 11(2), 186-194. https://doi.org/10.1108/14626000410537128

Union Europea (2001). Libro verde, promuovere un quadro europeo per la responsabilità sociale delle imprese. Green Paper www.europea.eu.int.

Van Gils, A., Dibrell, C., Neubaum, D. O., \& Craig, J. B. (2014). Social issues in the family Enterprise. Family Business Review, 27(3), 193-205. https://doi.org/10.1177/0894486514542398

Villalonga, B., \& Amit, R. (2004). How do family ownership, control and management affect firm value? EFA 2004 Maastricht Meetings Paper No. 3620. http://wgfa.wharton.upenn.edu/VillalongaAmit121004.pdf, accessed 14 March 2017.

Ward, J. L. (1987). Keeping the family business healthy. San Francisco, CA: Jossey-Bass.

Ward, J. L. (1999). Valores que sintetizan a las empresas familiares. In D. Melé Carné (Eds.), Consideraciones éticas sobre la iniciativa emprendedora y la empresa familiar. Navarra, ES: Editorial Eunsa.

Yu, A., Huang-Bin, D., \& His-Mei, C. (2015). Corporate social responsibility performance in family and non-family firms: The perspective of socio-emotional wealth. Asian Business Management, 14(5), 383-412. https://doi.org/10.1057/abm.2015.16

Yu, A., Lumpkin, G. T., Sorenson, R. L., \& Brigham, K. H. (2012). The landscape of family business outcomes: A summary and numerical taxonomy of dependent variables. Family Business Review, 25(1), 33-57. https://doi.org/10.1177/0894486511430329 
Zellweger, T. M. (2007). Time horizon, costs of equity capital, and generic investment strategies of firms. Family Business Review, 20(1), 1-15. https://doi.org/10.1111/j.1741-6248.2007.00080.x

Zellweger, T. M., \& Nason, R. S. (2008). A stakeholder perspective on family firm performance. Family Business Review, 21(3), 203-216. https://doi.org/10.1177/08944865080210030103

\section{Copyrights}

Copyright for this article is retained by the author(s), with first publication rights granted to the journal.

This is an open-access article distributed under the terms and conditions of the Creative Commons Attribution license (http://creativecommons.org/licenses/by/4.0/). 